\title{
2. 臨場感を探る
}

\section{1 仮想環境実現のための基盤技術}

廣 瀬 通 孝 $^{\dagger}$

\section{1. バーチャルリアリティとは何か}

最近, バーチャルリアリティと呼ばれる技術が注目 を集めつつある。バーチャルとは「実際には存在しな いが, 効果や機能において，それが存在すると同等で ある」という意味であり, リアリティとは「現実，現 実感」という意味である。つまり，バーチャルリアリ ティとは人工的な手段を用いて生成された現実のこと である。この技術を用いることによって，われわれの 周囲に展開する現実世界を模倣し，その中でいろいろ な擬似的な体験を行うことができるのである.

もともと，この技術はコンピュータグラフィックス の進化の方向のひとつ程度にしか考えられていなかっ た。しかしながら，実際にこの技術を使って合成され た映像世界を体験してみると，それが単なるインタラ クティブな映像体験以上のものであることがわかって きた，例えば，怨意的に合成された人工的な世界と現 実世界との間に本質的な差異がないのではないかとい う問いかけには, 現実とは何かという, かなり哲学的 な問題が含まれているのである.

われわれは外界に抢けるさまざまな出来事を, 自分 自身の感覚器官によって感じ取っているわけで, この 感覚入力こそが現実認識における基本である。したが って, この感覚器官への入力を何らかの手段で緻密に 合成してやることができれば，われわれはそれが現実 なのかそうではないのか知り得ないことになる。もち ろんこれまでは, 感覚入力を正確かつ本格的に合成し うる技術は実際には存在しなかったわけで, 現実と仮 想現実との区別は哲学的思考実験でしかなかった。 バ 一チャルリアリティの技術は, それを実験科学の場に ひきずり出したというわけである.

$\dagger$ 東京大学 工学部

"Basic Technologies for Virtual Environment" by Michitaka Hirose (Faculty of Engineering, University of Tokyo, Tokyo)

$960 \quad(8)$

\section{2. 仮想現実を合成するための機械装置}

\section{1 視覚的臨場感を生成するためのディスプレイ}

では,どのような仕組みによって感覚入力を合成し てやればよいのであろうか. 大切なことは, 感覚器へ の刺激入力が大部分が合成入力によって置換される必 要があるということである．視覚を例にとってみよ う。例えば，小さいブラウン管を眺めるということ は, 網膜のほんの一部にしか映像情報の刺激がないと いうことで，あとの部分には現実世界からの入力が残 っている. 例えば, 20 インチのブラウン管を $5 \mathrm{~m}$ の 距離から見るときの視野角は約 50 である。こういう 状況では, ブラウン管を見ている人間の意識は明らか に現実世界の側に存在する。つまり, 映像世界を第三 者として現実世界から眺めているようにしか感じな いであろう。

しかしながら, ブラウン管のインチ数を次第に大き くしていき，視覚全体における映像入力の割合を大き くすると, 人間の意識は現実世界から映像世界へと移 行する．例えば，摇動する水平線を映写したとき，そ れにつれて体が摇れはじめるのが視野角が $20^{\circ}$ ぐらい からである. 視野角が $80^{\circ} \sim 100^{\circ}$ ぐらいになると, 意 識はほとんど映像世界の中に入ってしまうといわれて いる. 人間の視覚は中心部だけが高い解像度を有して いるとはいうものの, 周辺視の部分も実はかなり大き な役割を果たしているのである.

\subsection{HMD}

写真 1 は, バーチャルリアリティの分野でよく利用 されているHMD (Head Mounted Display) と呼ば れるデバイスである.これは, 光学系を介して眼球直 前にディスプレイを装着したもので, $30^{\circ} \sim 80^{\circ}$ とい う, 従来の常識からいえばきわめて大きい視野角の映 像を表示することができ, きわめて高い映像世界への 没入感を実現することが可能である。しかも，頭部の 3 次元的な動きを常に映像表示にフィードバックする

テレビジョン学会誌 Vol. 48, No. 8, pp: 960９65 (1994) 


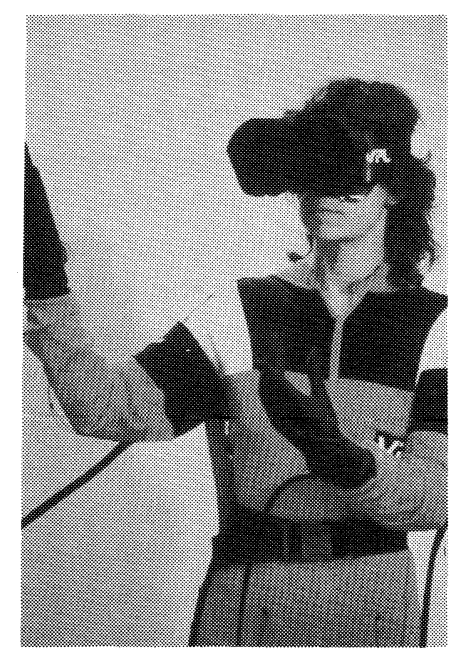

写真 1 HMD (Head Mounted Display)

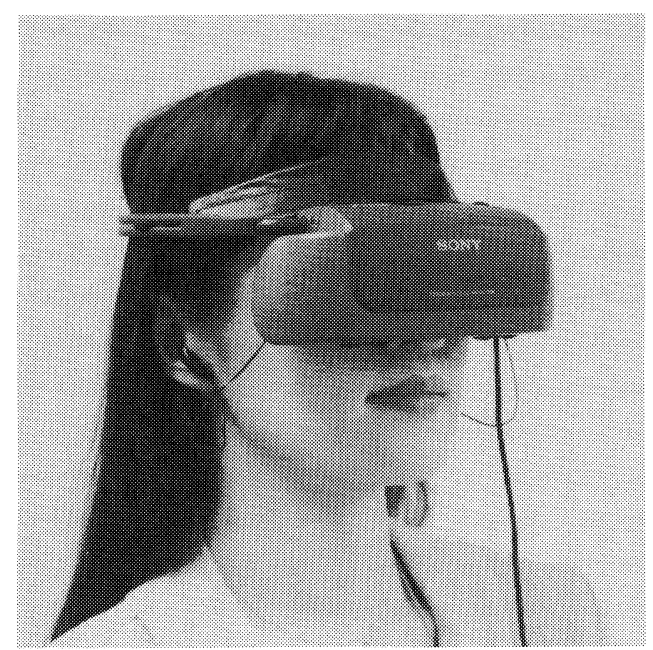

写真 2 Sony のバイザートロン

ことにより，自分の周囲 $360^{\circ}$ すべてを見回すことが できる.

もちろん, HMD はまだ発展途上のデバイスであ り，技術的にみても克服すべき問題点は少なくない. 最も大きな問題は小型化と軽量化であろう. 写真 2 は，一昨年にソニーが発表したバイザートロンと呼ば れる HMD の一種である. 約 10 万画素を有する 0.7 インチ LCD（液晶ディスプレイ）を用いることによっ て, 重量を約 $300 \mathrm{~g}$ 程度に抑えることに成功してい る.もっとも 10 万画素程度では, まだ現在の NTSC レベルの解像度すら実現できないため, 視野角は $30^{\circ}$ 程度に止められている.

現在, 手っ取り早く解像度を高めようとすれば, LCD ではなく小型の CRT を使用する必要がある.

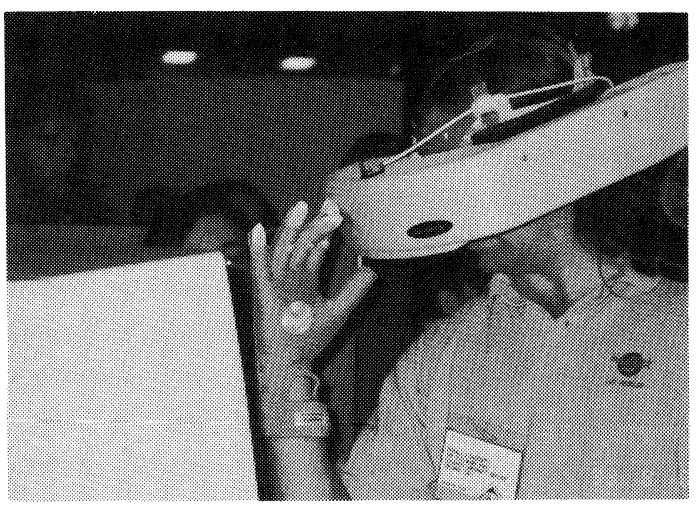

写真 $3 \mathrm{n}-\mathrm{V}$ ision 社の高解像度 HMD

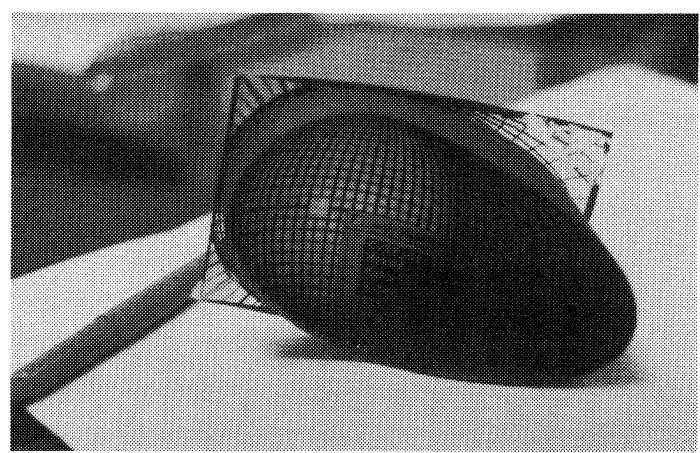

写真 4 視野角 $180^{\circ}$ を実現するための特殊光学系

しかしながら，カラーの小型 CRT を製作することは 容易ではない．小型のシャドウマスクの製作が困難だ からである。そこで, モノクロ CRT の前面に RGB 3 原色に変化するカラーフィルタを設置し, それに同 期させてそれぞれの色の画像を時系列的に表示し, 残 像現象によってカラー表示を行うことが考えられてい る. 写真 3 は, この小型 CRT を用いた HMD の例で あり, 重量は $1 \mathrm{~kg}$ 以上あるが, $1280 \times 960$ というきわ めて高い解像度を有している。

HMD において, 光学系の設計もまた重要である.

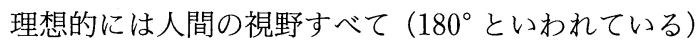
にわたって映像の表示範囲を広げる必要があるわけ で，そのためには従来にない光学系を設計する必要が ある. 写真 4 に示すような特殊レンズは, 眼球のごく 近傍に装着された球款状のスクリーンの上に, $180^{\circ}$ 分の映像を光ファイバ束を利用して投影するためのも のである．焦点調節はコンタクトレンズを使用して行 われる。

究極の HMD は, 外部に LCD や CRT のような表 示デバイスを置くのではなく, 網膜に直接描画を行う タイプのVRD (Virtual Retinal Display) であろう. 


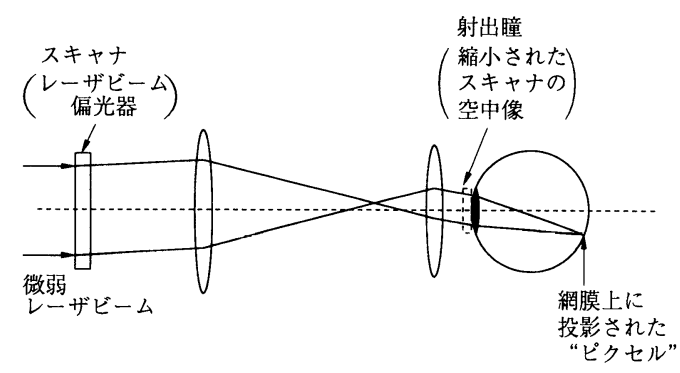

図 1 VRD (Virtual Retinal Display)

これは, 眼球内部に微弱なレーザ光を入射させて網膜 上をスキャンし，2 次元の映像を表示しょうというも のである．この場合, 外部には小さな LED（レーザ 発光素子) とスキャン用の光学系を置くだけであり, きわめてコンパクトかつ高性能なディスプレイを構成 することができる(図 1).

\section{3 全天周型ディスプレイ}

HMD を用いることが映像への没入を可能にする唯 一の方策ではない。もっと簡単に, 大型スクリーンを ユーザの全周囲にはりめぐらすことも考えられる. OMNIMAX と呼ばれるシステムは, 球殼状のスクリ ーンの内側に 70 ミリフィルムの全天周映像を投影し, 非常に高い臨場感を与えることができる。また SIGGRAPH'92 においてイリノイ大学のグループがデモ ンストレーションを行った“CAVE”と呼ばれるシス テムは，4台のステレオプロジェクタを使用して， OMNIMAX と同様な効果を持たせたものである.

CAVEは, 現在広く利用可能な商品を用いて比較 的簡単に構成できるところがすぐれている．以前では

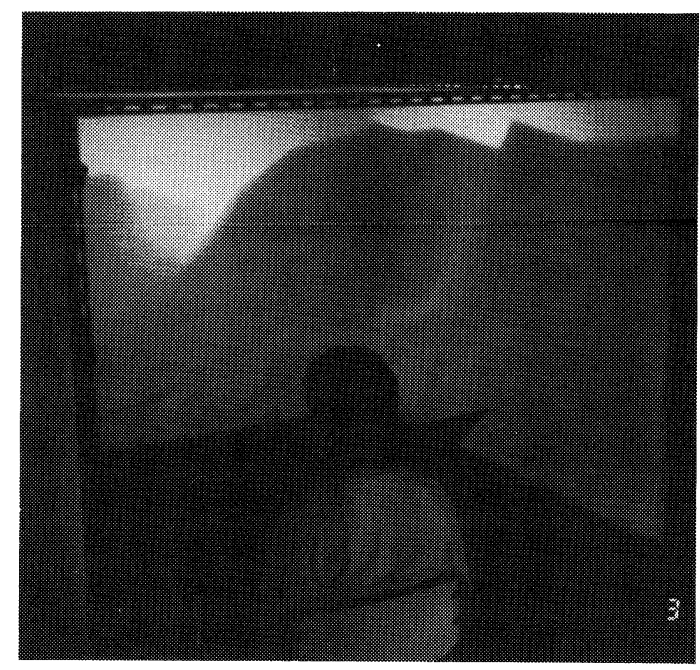

写真 5 「はいれるテレビ」

プロジェクタがかなり高価であったが, 最近では液晶 を利用したかなり安価なものが商品化されている。こ のシステムは何人もが同時に体験できるために, ある 意味では HMD よりずっと現実的なものである. 本 年の 3 月, 国立小児病院で行われた「やさしい小児医 療を求めて」に展示された「はいれるテレビ」も同様 なシステムである (写真 5).

\section{4 その他のディスプレイ}

さて, 視覚以外の感覚についても, いろいろなディ スプレイが考案されている。例えば, 図 2 は 3 次元の 音響ディスプレイである。われわれの外界認識におい て視覚が支配的であることはいうまでもないが, 聴覚 もまた非常に大きな役割を果たしている，真暗闇の中

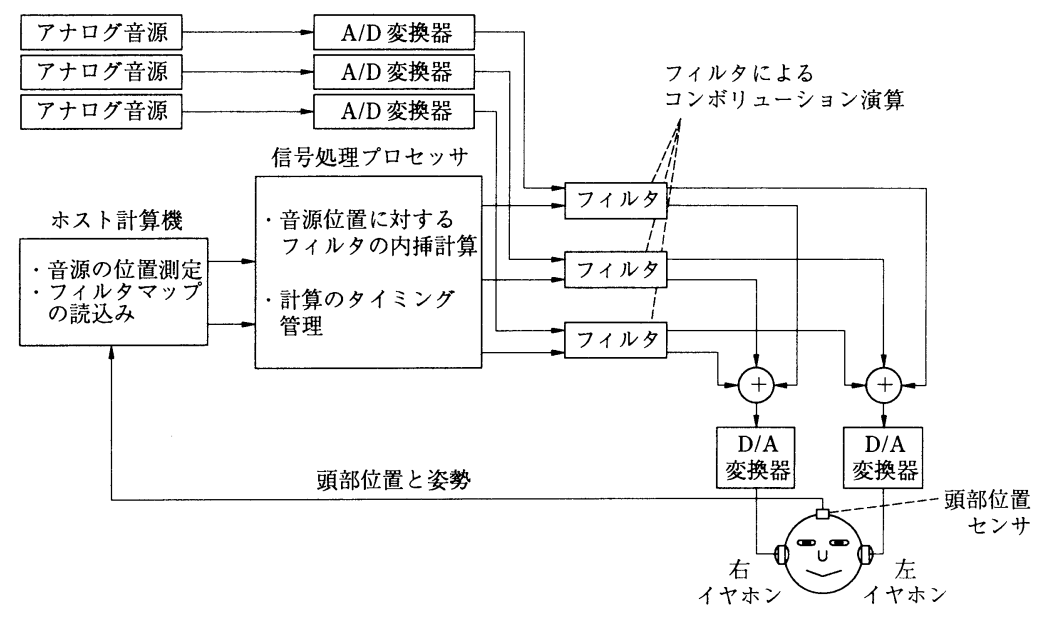

図 23 次元の音響ディスプレイ 


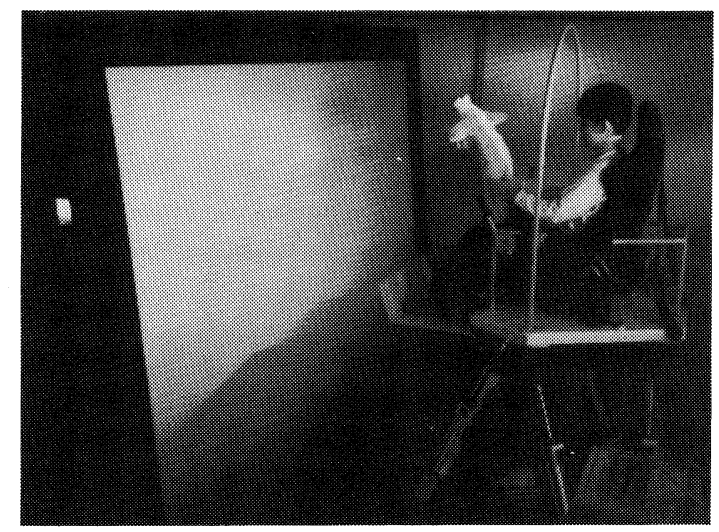

写真 6 東京大学人工物工学研究センタの前庭感覚デ イスプレイ

でも，音の反響によって自分の居る部屋の大きさを判 断することが可能である。このディスプレイは，音源 から両耳鼓膜までの波形の変化をシミュレートし， 3 次元空間内に仮想の音源を定位させることができる． さらに，音源からの音波の反射や遮蔽をシミュレート することによって, よりリアルな聴覚的臨場感を作り 上げることが可能である．臨場感に富んだ録音ができ るシステムとしてダミーヘッド録音が知られている が，このシステムはダミーヘッド方式を計算機でシミ ュレートしたものと考えればよい.

乗り物に乗ったときに感ずる加速感や振動感などは 前庭感覚と関連がある。この感覚の合成のためには， 自由に運動できる振動台を使用することが多い.このよ うな仕組みは，もともとはフライトシミュレータで使 用されていたが，最近ではゲームマシンなどにも採用 されるようになってきた，写真 6 は，東京大学人工物 工学研究センタに設置された前庭感覚ディスプレイで ある．6本の油圧シリンダによって支えられた座席は 6 つの自由度を持ち, 中立位置では 3 次元空間内の各 方向あたり $0.5 \mathrm{G}$ の加速度を発生することができる. この装置と大画面ディスプレイや HMD を組合せれ ば，仮想空間の内を高速で動き回る，いわゆるフライ スルーのシステムを作り上げることができる．

物体に触れた感じを作り上げるためには, 触覚ディ スプレイが必要となる. 写真 7 は，ノースカロライナ 大学で試作された触覚ディスプレイである．ユーザが 握っているのは，いわゆるマジックハンドである．通 常のマジックハンドの先には実際のロボットハンドが 接合されているが，この場合には，分子と分子との相 互作用力をシミュレーションするプログラムが接続さ れており，計算された力がマジックハンドの手先にフ

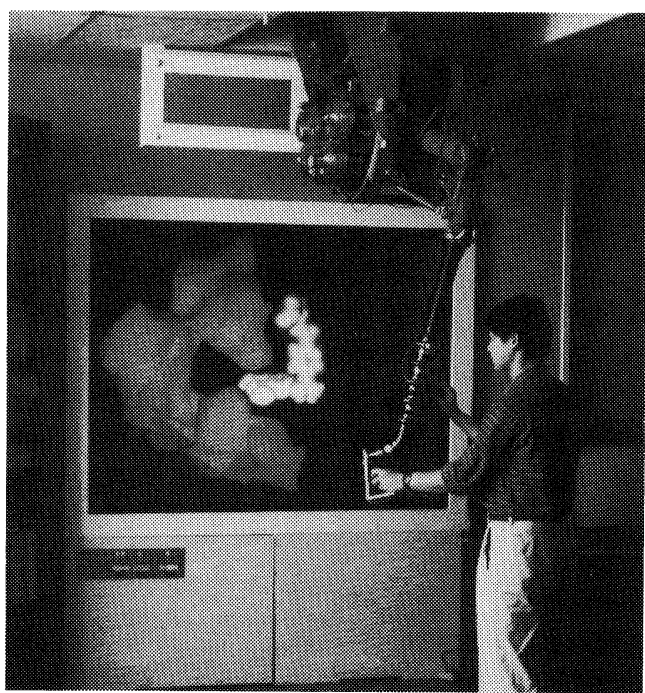

写真 7 ノースカロライナ大学の触覚ディスプレイ

イードバックされるというわけである.

\section{3. 仮想現実を操作するための機械装置}

ディスプレイが完成したとして, 次に重要なこと は，この世界を自由に操作することである。つまり， システムの作り上げた仮想現実の情報をユーザが一方 的に受容する装置だけではなく，その逆の方向の情報 フローを司る装置を作り上げる必要があるのである.

バーチャルリアリティのシステムに計算機を使うこ との意義のひとつがここにある。つまり，ユーザの操 作入力に対して, システムがリアルタイムで反応しな ければならない。これによって, 映画とは根本的に異 なる映像世界が作り上げられるのである。もちろん， これまでも計算機科学の諸分野において人間とシステ ムとの対話的関係は重要視されているが, バーチャル リアリティの分野で追求されているのは，もっとずっ とわれわれの身体感覚に忠実な対話性である。

例えば図 3 は，データグローブと呼ばれる手袋型の デバイスである。これは人間の手指のジェスチャをそ のまま計算機に対して入力するために使われる。これ を 3 次元の空間位置センサと併用することによって, 仮想の物体をつかんだり，持ち上げたりすることがで きる．この種のデバイスを利用して器用な操作を行う ためには，手の動きをどれだけ忠実に測定しうるかが 重要である.データグローブの革命的なところは, 光 ファイバを用いて，1本あたり 2 関節，手全体で 10 関節分の曲げ角度を測定できるという点である。最近 のサイバーグローブは 16 の自由度を持ち, 指の開き 


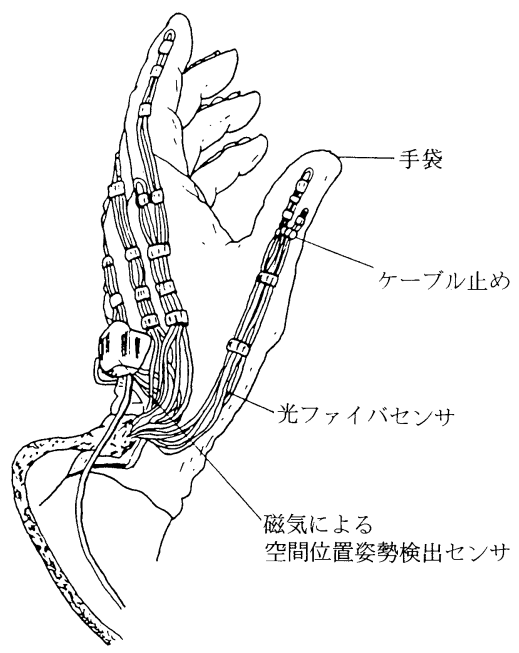

図 3 VPL 社のデータグローブ

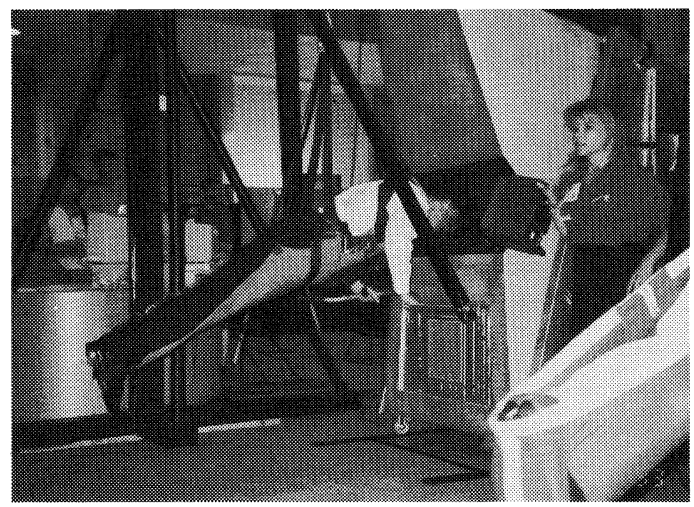

写真 8 SIGGRAPH'93で展示されたハンググライ ダの擬似体験システム

角度も測定できるなど, より一層複雑な手指の動きが トレースできる。

もちろん, センサの個数さえ増えれば器用な物体操 作が可能になるわけではない. 物体表面からの反力に よって，指先が拘束されることも重要である.したが って, 入力デバイスと触覚ディスプレイはかなり密接 な関係にある。もともと触覚は視覚などと違い, 手を 伸ばして物体に触れてはじめて感ずる, 双方向性の強 い感覚である.したがって, 触覚ディスプレイと入力 デバイスの境界はかなりあいまいである。

写真 8 は, SIGGRAPH'93 で展示されたハンググ ライダの擬似体験システムで使われた入力装置であ る。このように体全体の運動を使用する入力システム はまだ一般的とはいえないが, 今後いろいろなところ
で使われていくことになるかも知れない．

\section{4. 仮想現実のレンダリング}

ところで, 以上述べたような装置は，ユーザを人工 の仮想世界と結びつけるためのインタフェース装置で ある。それに加えて，もうひとつ重要なのが, シミュ レートされた仮想世界をディスプレイに表示できる形 に変換するための仕組み, すなわちレンダリングソフ トである。

この場合, 最も重要な技術のひとつがコンピュータ グラフィックスであろう。昨年公開された「ジュラシ ック・パーク」の映像から明らかなように，この技術 を用いることによって，実物とほとんど見まがうばか りの光景を作り上げることがすでに可能である．ただ し問題は，1枚の絵の生成時間であって，インタラク ティブなシステムを構成しようとすると，まだまだ計 算機の能力は充分とはいえない，映画のセットにおけ る書き割りのように, 複雑な 3 次元の構造を作らずに 絵を表面に貼り付けてすますような,表現上のテクニ ックがきわめて重要である。レイトレーシングのよう に, 現実世界の光学現象を忠実にシミュレーションす る方法論を使った仮想世界を体験するためには，現在 の計算機の能力を 4 〜 桁向上させなければならない であろう。

もうひとつ重要な技術が動画圧縮技術である．コン ピュータグラフィックスにせよ, 実写の映像にせよ, あらかじめ作成しておいた映像データを選択的に使用 することによって，ある程度の対話性を実現すること ができる。この場合, 必要なことは充分な映像デー夕 ベースをあらかじめ作って保存しておくことである. ただし， $600 \times 400$ 画素の画像ですら，M（メガ）ビッ 卜の情報量を持つため, 映像データベースは巨大であ る。そのままでは例えば，1 分の動画像を記録するた めには， 1 秒 10 コマとしても $\mathrm{G}$ (ギガ) ビットという 大容量の記憶媒体が必要である。しかしながら, 昨今 の MPEGなどのような画像圧縮技術を用いれば，少 なくともこのデータを $1 / 10$ 程度に圧縮することが可 能である.したがって, 数 $\mathrm{G}$ 程度の高速ディスクを 用いれば，数 10 分の動画像を記録することが可能で ある.さらに, 最近では CD $\mathrm{CD}$ などの新しい記憶 媒体も利用可能であり, こういう方法論による仮想世 界の創出法がリアルタイム CGによるそれを凌駕する 可能性は大きい. 最近, 注目を集めている 3 DO など のゲーム機など, こういう手法を使用しているものも 少なくない。 


\section{5.むす び}

かつて「環境」とは，われわれ人間が制御すること の不可能な「自然環境」であった。人間はさまざまな 人工物を用いることによって自然環境を克服すること を試みてきた，ところが今や，われわれの周囲は道具 であった筈の人工物であふれかえっている。「自然」

は，われわれの目の前から姿を消しつつある。バーチ ヤルリアリティによってつくられる仮想環境は, 人工 物としての環境である。この場合, 環境と人工物の関 係ははるかに複雑である.今, われわれは環境と人工
物, そして人間とのかかわりを, 改めて考え直す必要 があるのである. バーチャルリアリティの技術は, 21 世紀に向けての新しいテーマを示唆しているというこ ともできるのである.

(1994 年 4 月 14 日受付)

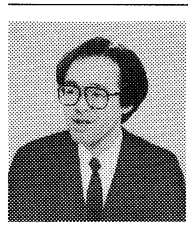

廣瀬 通孝 昭和 52 年, 東京大学工学部 産業機械工学科卒業. 昭和 57 年, 同大学院 博士課程修了。同大学工学部産業機械工学科 専任講師, 昭和 58 年, 助教授, 平成 3 年, 機械情報工学科助教授となり, 現在に至る。 工学博士.

\title{
2-2＼cjkstart視覚情報と身体運動の相互作用
}

\author{
正会員 清 水 俊 宏 ${ }^{\dagger}$, 正会員 三 橋 哲 雄 $^{\dagger}$
}

\section{1. ま え がき}

博覧会やアミューズメントパークなどで上映される ドーム型の巨大なスクリーン映像を見ていると，あた かも実際に自分がその映像の中にいるような感覚を生 じる. 特に空撮シーンでは, 飛行機が旋回して地面が 傾くと, 自分がいっしょになって旋回しているよう な, より強い感覚を生じる. 列車の先頭車両から撮影 された映像を見た場合でも，自分が前進している感覚 を生じる.これは, 視覚系からの情報によって自己の 運動を認識するメカニズムが働くために生じる自己運 動感覚であり，ディスプレイによって与えられる臨場 感と密接な関係がある.このような広視野画像によっ て与えられる心理効果の定量化の試みとして, 主観的 座標軸の誘導量を測定する心理物理学的な方法が提案 されている1).

本稿では, 視覚情報と身体運動の相互作用のうち, 自己運動感覚において視覚系が果たす役割について述 ベる。はじめに, 観察者の脳内空間地図が姿勢制御系 に果たす役割を視覚情報との関係から述べる. 次に, 立体視と姿勢制御との関係を調べた実験について紹介 する。

$\dagger$ NHK 放送技術研究所

"Interaction between Visual Information and Self-Motion" by Toshihiro Shimizu and Tetsuo Mitsuhashi (NHK Science and Technical Research Laboratories, Tokyo)

\section{2. 空間の認知}

\section{1 脳内空間地図}

われわれは, 空間上を自由に動き回っている場合で も, 自己の運動を的確に把握しつつ, 周囲の状態(物 体の位置, 運動等)をも的確に知覚することができる. このとき, 網膜上を動く像は眼球に固定された眼球座 標系上で動き, 視覚情報として大脳皮質に伝達され る.しかし, 眼球は頭部に固定された頭部座標系上で 眼球運動を行っており，頭部は身体に固定された身体 座標系上で動く，そして, 身体座標系は, 周囲の空間 に存在する外界座標系上で運動する。このような多重 化された座標系構造 ${ }^{2}$ の中でも, われわれは外界座標 系での自己運動と周囲の物体の運動を区別して認識す ることができる。

したがって, 脳は, 視覚を含む各種の感覚を統合 し, 外界座標系で表現された周囲の空間地図を内部に 構築しているものと考えられる.この周囲空間を表し た地図は脳内空間地図 ${ }^{314)}$ と呼ばれ，姿勢制御といっ た運動制御も脳内空間地図をもとにして行われている ものと考えられる.

\section{2 姿勢制御と脳内空間地図}

図 1 は, 人間の姿勢制御系における情報の流れを示 したものである. 視覚系は, 網膜からの情報を受容 し, 外界と自己の相対的な位置情報を処理する. 前庭 迷路系は, 内耳の中の平衡器官により頭部の直線加速 